International Journal of Engineering \& Technology, $7(4.38)(2018)$ 1197-1199
International Journal of Engineering \& Technology
SPC
Website: www.sciencepubco.com/index.php/IJET
Research paper

\title{
Mathematical Model for Filling in the Dome-Separator Plant for the Elimination of the Near Bottom Hydrocarbon Flow
}

\author{
${ }^{1}$ Bashkir State University, Birsk Branch, Russia \\ ${ }^{2}$ Industrial University of Tyumen, Surgut Branch, Russia \\ *Corresponding author E-mail: azat.a.nasyrov@bk.ru
}

Azat Askatovich Nasyrov ${ }^{1 *}$, Igor Aleksandrovich Chiglintsev ${ }^{1}$, Sergey Anatolievich Lepikhin ${ }^{2}$

\begin{abstract}
The work presents a mathematical model for the hydrocarbon crude extraction from the bottomhole zone by a cylindrical dome-separator. The proposed model allows determining the thermobaric conditions and dynamics of the boundaries of stratified phases in the installation during its operation and analyzing the complications associated with the possibility of formation of gas hydrates.
\end{abstract}

Keywords: Gas Extraction, Hydrate, Dome-Separator, Hydrocarbons.

\section{Introduction}

An important problem in oil recovery is the prevention of the consequences of uncontrolled discharge of hydrocarbon raw materials into the world ocean waters. The examples of such accidents include well breakouts in the Gulf of Mexico in 2010 and gas leakage at a producing platform in the North Sea in March 2012 The use of a dome-separator seems to be the most effective method of preventing such emissions $[1,2]$. But this method leads to the formation of hydrates at the depths, corresponding to the conditions of their formation, which in the future may pose a problem for further pumping of hydrocarbons. Many publications have been devoted to hydrate formation mechanisms, for example [3-9].

Consider a dome-separator of a cylindrical shape, which will eliminate the formation of hydrate mass during the operation of the separator.

This work continues and further develop the works [10, 11], considering the hydrate strata depletion for various materials from which the dome-separator is made.

\section{Basic equations}

Figure 1 shows a schematic diagram of a cylindrical domeseparator, which is installed on the ocean floor, directly above the accident site. The segregation order shown is due to their densities (z)s

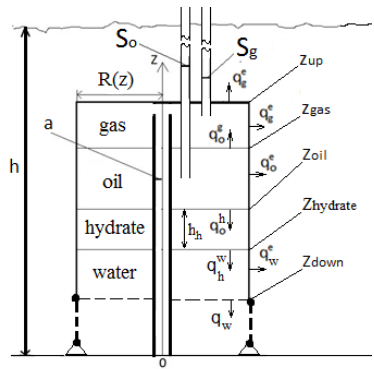

Fig. 1: Schematic diagram of the dome-separator
Where $R(z)$ - a dome radius; $a$-a well radius; $z_{\text {up }}, z_{\text {down }}-$ the coordinate of the upper and lower boundaries of the dome; $z_{\text {gas }}$ , $z_{\text {oil }}, z_{\text {hydrate }}$ - an interface between the phases "oil-gas", "oilhydrate" and "hydrate-water"; $h$ - the distance from the surface to the ocean floor; $S_{o}, S_{g}$ - the sectional area of pipes for pumping oil and gas; $h_{h}$ - the thickness of the hydrate layer.

The description of the change in the level of oil and gas during the filling of the dome-separator, assuming that there is no mass exchange between them, will be written as the equations of conservation of mass of hydrocarbons [12]:

$$
\frac{d M_{j}}{d t}=m_{j}
$$

$$
\begin{aligned}
& M=\int_{z_{j}}^{z_{j+1}} g \cdot I(z) d, \quad I(z) \Rightarrow(z) \dot{a}, \\
& \left(z_{j}<z<z_{j+1}\right),
\end{aligned}
$$

where $M_{j}$ - the mass of the phases; $\rho_{j}$ - the density of phases; $F(z)$ - the sectional area of the dome in the coordinate $z ; m_{j}^{+}$ ,$m_{j}^{-}-$input and extracted mass flow and gas consumption in the dome $(j=g, o)$.

The conservation of the mass of water in the dome will be described by the equation:

$$
\frac{d \pi}{d t} \tan \left(t_{4}\right)
$$

where $M_{w}$ - the mass of water; $w_{w}$ - the rate of the water flow from the dome. 
Conservation of mass of hydrate can be represented as follows:

$$
\frac{d M}{d t}=F\left(z_{n}\right) j_{h}
$$

where $M_{h}$ - the mass of the hydrate; $j_{h}$ - the intensity of the hydrate formation from an oil contact area unit.

To determine the average temperature of the phases in the dome, use the energy conservation law:

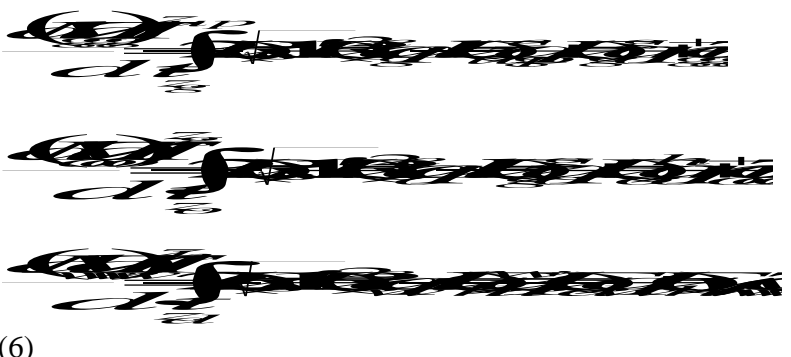

$$
R(z)=\frac{d R)}{d z}
$$

where $q_{g}^{e}, q_{o}^{g}, q_{o}^{e}, q_{o}^{g}, q_{o}^{h}, q_{w}^{e}, q_{h}^{w}, q_{w}$ - heat fluxes shown in Figure $1 ; c_{g}, c_{o}$-specific heat capacity of phases; $T_{g}^{+}$ ,$T_{o}^{+}$-the temperature of input gas and oil; $T_{g}, T_{o}, T_{w}$-current average temperatures of the phases.

To determine the phase pressures in the upper part of the dome, use the hydrostatic balance condition:

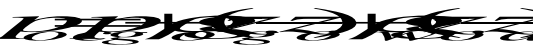

where $p_{o c-\text { the pressure of the liquid column at the depth }} h_{;} p_{g}$ - gas pressure under the dome; $\rho_{j}$ - phases density; $z_{j}, z_{d}$ the coordinates of the boundaries of the phases and the lower base of the dome.

\section{Description of heat and mass exchange}

To close the reduced system, write the equation for the intensity of hydrate formation using the heat balance condition at the phase boundary:

$$
\dot{j}_{h}=\frac{-\hat{q}^{h}+q_{h}^{w}}{l}
$$

here $q_{o}^{h}, q_{h}^{w}$ - heat flows from the oil to the hydrate layer and from the hydrate to the water.

The heat fluxes between the phases inside the dome-separator are described in the form [13]:

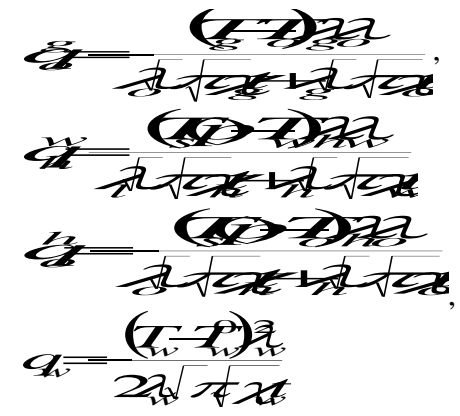

where $q_{o}^{g}, q_{o}^{h}, q_{h}^{w}$ - the intensity of heat exchange per unit of contact area between oil and gas, oil and hydrate, hydrate and dome water layer, respectively, $q_{w}$ - the heat exchange between the layer of water in the dome and under the dome per unit of contact area, $\lambda_{j}-$ coefficient of thermal conductivity of phases $(j=\boldsymbol{g}, \boldsymbol{O} \boldsymbol{h} \mathbf{h} W) ; \chi_{j}$ - thermal diffusivity of phases; $t$ - the time, counted from the start of filling in the dome with the hydrocarbon mixture.

According to the data given in [14], the biggest part of the associated gases is methane. Therefore, the temperature at the boundary $z_{h}$ will be considered equal to the balance temperature of hydrate formation corresponding to the pressure $p_{o c}$, which, as noted in the works [15-18], for most hydrate-forming media (in particular, for methane and water), is well described by the empirical formula:

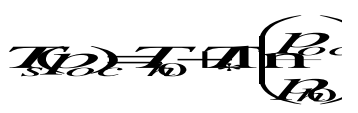

where $T_{h 0}, p_{h 0}, T_{*}$ are empirical parameters.

Assume that the dome fills in for several days. Then, the motion of the phase boundaries is assumed to be at rest, which corresponds to the conditions for natural heat exchange through the dome wall. Therefore, to describe the thermal interaction of the phases with the surrounding ocean water through the wall of the dome-separator, adopt the following relations [19]:

$$
\begin{aligned}
& \bar{q}=f\left(T_{j}-T_{c}\right), q=f\left(T_{c}-T_{c}^{+}\right), \bar{q}=f\left(T_{c}^{+}-T_{w}^{\prime}\right. \\
& \beta_{c}=\frac{\lambda_{j} N \boldsymbol{y}}{2 R(z)}, \beta_{c}=\frac{\lambda_{c}}{\delta}, \beta_{c}=\frac{\lambda_{1} N \underline{W}}{z_{j+1}-z_{j}}
\end{aligned}
$$

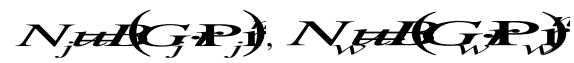

where $q_{j}^{-}$- the intensity of heat exchange between the phases and the internal surface of the dome-separator wall per unit area of this wall $(j=g, O, w), q_{c}$ - the intensity of heat transfer through the wall of the dome per unit area of this wall area, $q_{c}^{+}-$the heat exchange between the outer surface of the installation wall and the surrounding oceanic water per unit area of this wall, $T_{c}^{-}-$the temperature of the inner surface of the wall of the dome-separator, $T_{c}^{+}$- the temperature of the outer surface of the wall of the dome installation, $N u, G r, \operatorname{Pr}$ - the Nusselt, Grashof and Prandtl numbers, $B$ and $n$-the empirical constants for a vertical surface, $\lambda_{c}$ - the wall material thermal conductivity ( $\lambda_{p}$ - polyurethane, $\lambda_{s t}-$ steel), $\delta$ - the thickness of the dome wall.

The heat flows $q_{j}^{-}, q_{c}, q_{c}^{+}$must be equal, therefore from (11) obtain:

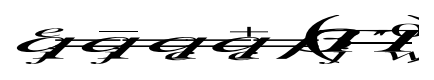

where

$\frac{1}{\beta}=\frac{1}{\beta}+\frac{1}{\beta}+\frac{1}{\beta}$

To simplify the task, assume that gas extraction to the ocean surface is not implemented. 


\section{Conclusions}

The above-mentioned system of equations can be solved by numerical methods (particularly, by the Runge-Kutta method of the 4th order of accuracy) and allows describing such parameters as the movement of the phase boundaries, gas temperature and pressure inside the installation and changing the thickness of the gas hydrate layer formed during the start-and-installation work.

\section{References}

[1] Zhukov AV, Zvonarev MI, Zhukova YuA (2013), Sposob dobychi gaza iz glubokovodnykh mestorozhdeniy gazogidratov [Method of gas production from deep-water gas hydrate deposits] Mezhdunarodnyy zhurnal prikladnykh i fundamental'nykh issledovaniy, 10(1), 16-20.

[2] Gimaltdinov IK, Kildibaeva SR (2015), K teorii nachalnogo etapa nakopleniya nefti $\mathrm{v}$ kupole-separatore [To the theory of the initial stage of oil accumulation in the dome-separator]. Teplofizika $i$ aeromekhanika 22(3), 401-406.

[3] Makagon YuF (1974), Gidraty prirodnykh gazov [Hydrates of natural gases]. Moscow: Nedra.

[4] Istomin VA, Yakushev VS (1992) Gazovye gidraty v prirodnykh usloviyakh [Gas hydrates in natural conditions]. Moscow: Nedra.

[5] Stephen M, Masutani E, Adams E (2003), Experimental study of multi-phase plumes with application to deep ocean oil spills. Final report of U.S. Department of the Interior. Minerals Management Service. Hawaii: University of Hawaii.

[6] Mingjun Y, Yongchen S, Yu L, Yongjun C, Qingping L (2010), Influence of Pore Size, Salinity and Gas Composition upon the Hydrate Formation Conditions. Chinese Journal of Chemical Engineering, 18(2), 292-296.

[7] Shagapov VSh, Tazetdinov BI (2013), K teorii razlozheniya metastabil'nogo gazogidrata [To the theory of decomposition of metastable gas hydrate]. Teoreticheskie osnovy khimicheskoy tekhnologii, 47(4), 454-463.

[8] Shagapov VSh, Tazetdinov BI, Nurislamov OR (2013), K teori obrazovaniya i razlozheniya gazogidratnykh chastits $v$ protsesse ikh vsplytiya $v$ vode [To the theory of formation and decomposition of gas hydrate particles in the process of their ascent in water]. Vestnik tomskogo gosudarstvennogo universiteta. Matematika i mekhanika 6(26), 106-113.

[9] Shagapov VSh, Chiglintseva AS, Rusinov AA (2015), O migratsi puzyr'kov v usloviyakh obrazovaniya gidrata [On the migration of bubbles in the conditions of hydrate formation]. Prikladnaya mekhanika i tekhnicheskaya fizika, 2

[10] Nasyrov AA (2015), Modelirovanie protsessa napolneniya «kupola - separatora», prednaznachennogo dlya likvidatsii neftegazovykh vybrosov v zone morskogo dna [Modeling of the filling process of the "dome-separator" intended for liquidation of oil and gas emissions in the seabed zone]. Vestnik Kemerovskogo gosudarstvennogo universiteta, 2(62(1)), 41-45.

[11] Chiglintsev IA, Nasyrov AA (2016), Modelirovanie protsessa napolneniya «kupola-separatora», s razlozheniem gazogidrata, obrazovavshegosya $\mathrm{v}$ period montazha ustanovki [Modeling the filling process of the "dome-separator", with the decomposition of the gas hydrate formed during the installation of the unit]. Inzhenerno-fizicheskiy zhurnal, 4(89), 851-860.

[12] Kildibaeva SR (2013), Modelirovanie kupola-separatora pri razlive nefti $v$ shel'fe [Simulation of the dome-separator in the case of oil spills in the shelf]. Fundamental'nye issledovaniya, 10(5), 1045 1050 .

[13] Tikhonov AN, Samarskiy AA (2004), Uravneniya matematicheskoy fiziki [Equations of mathematical physics]. Moscow: Izd-vo MGU.

[14] Gimatudinov ShK (1971), Fizika neftyanogo i gazovogo plasta [Physics of the oil and gas reservoir]. Moscow: Nedra.

[15] Byk SSh (1980), Gazovye gidraty [Gas hydrates]. Moscow: Khimiya.

[16] Nigmatulin RI, Shagapov VSh, Syrtlanov VR (1998), Avtomodelnaya zadacha o razlozhenii gazogidratov $\mathrm{v}$ poristoy srede pri depressii i nagreve [A self-similar problem on the decomposition of gas hydrates in a porous medium under depression and heating]. PMTF, 39(3), 111-118.
[17] Shagapov VSh, Chiglintseva AS, Syrtlanov VR (2009), O vozmozhnosti vymyvaniya gaza iz gazogidratnogo massiva posredstvom tsirkulyatsii teploy vody [On the possibility of leaching gas from the gas hydrate array by circulating warm water]. Prikladnaya mekhanika i tekhnicheskaya fizika, 50(4), 100-111.

[18] Shagapov VSh, Chiglintseva AS, Belova SV (2016), Matematicheskoe modelirovanie nagnetaniya gidratoobrazuyushchego gaza $\mathrm{v}$ snezhnyy massiv, nasyshchennyy tem zhe gazom [Mathematical simulation of injection of hydrateforming gas into a snow mass saturated with the same gas]. Trudy Instituta mekhaniki im. R.R. Mavlyutova Ufimskogo nauchnogo tsentra RAN, 11(2), 233-239.

[19] Kutateladze SS (1979), Osnovy teorii teploobmena [Heat exchange basics]. Moscow: Atomizdat. 